\title{
CURRENT TRENDS IN E-LEARNING DEVELOPMENT
}

\section{Hana MAREŠOVÁ-Milan KLEMENT}

\begin{abstract}
The article focuses on the analysis the new possibilities of e-learning development, which is currently reaching its limits in both of e-learning applications and the e-learning distance study supports created in text forms with using multimedia. There are analyzed the possible outlines of development towards to the use of multiuser virtual environment in e-learning education.
\end{abstract}

Key words: e-learning, multiuser virtual environment, information and communication

\section{SOUČASNÉ TRENDY ROZVOJE E-LEARNINGOVÉHO VZDĚLÁVÁNÍ}

Resumé: Př́spěvek je zaměřen na analýzu nových možností vývoje e-learningového vzdělávání, které v současné době naráží na své limity jak v oblasti samotných e-learningových aplikací, tak v př́ipadě e-learningových distančních studijních opor vytvářených $\mathrm{v}$ textové podobě $\mathrm{s}$ využitím multimédií. Jsou analyzovány aspekty možného vývoje směrem $\mathrm{k}$ využití multiuživatelských virtuálních prostředí v e-learningovém vzdělávání.

Klíčová slova: e-learning, multiuživatelské virtuální prostředí, informační a komunikační technologie.

\section{1 Úvod}

K nejdynamičtěji se rozvíjejícím konceptům v oblasti počítačově podporovaného vzdělávání patří v posledních letech bezesporu e-learning. Pedagogická encyklopedie (Průcha a kol., 2009) jej šíreji definuje jako „,vzdělávací proces (s různým stupněm intencionality), $v$ němž jsou používány informační a komunikační technologie (ICT), které pracují s daty v elektronické podobě (např. počítače, počítačové programy, multimédia, interaktivní tabule, internet, digitální televize nebo rádio, videokonference).“ $\mathrm{M}$. Klement (2011) řadí $\mathrm{v}$ tomto pojetí $\mathrm{k}$ jeho základním rysům zejména možnost využít při výuce elektronické distanční studijní texty (častěji také elektronické studijní opory), které obsahují několik nosičů vzdělávacího obsahu, jež jsou velmi často multimediálního charakteru. Tradičně se rozlišují dvě základní formy elearningu - offline forma, která nevyžaduje připojení počítače $\mathrm{k}$ internetu, přičemž učební materiály jsou distribuovány na přenosných pamětových nosičích (CD, DVD, USB apod.), a online forma, využívající počítačových sítí (výuka prostřednictvím webových stránek či Learning Management Systémů (LMS)). Zde dále rozlišujeme synchronní a asynchronní způsob výuky (D. Nocar, 2004). Synchronní výuka, vyžadující bezprostřední komunikaci mezi učitelem a studujícím, vyžaduje neustálé připojení $\mathrm{k}$ síti, komunikace se uskutečňuje v reálném čase (např. komunikací ve virtuální trrídě, v chatové komunikaci, multiuživatelském virtuálním prostředí apod.). Při asynchronním zpưsobu výuky není nutná komunikace $\mathrm{v}$ reálném čase, proto ke komunikaci může docházet se zpožděním, např. formou e-mailu, diskuzních fór apod.

\section{Limity dosavadních e-learningových forem}

V současné době je velektronickém vzdělávání stále častěji před čistě e-learningovou formou upřednostňována forma tzv. blended learningu, tedy kombinace tradiční prezenční výuky a samostatného studia v některé z e-learningových forem. Formát e-learningu jako jednotvárného, osamoceného učení pro sebe před počítačovou obrazovkou dnes představuje přkenonaný směr. Podle výzkumů (Aimard, Mc Cullough, 2006) totiž nemohou ICT zcela nahradit sociální dimenzi učení a lidskou komunikaci při výuce, proto dává řada respondentů přednost této formě. To dokladuje i vzdělávací praxe - napřr. v Goethe-Institutu si v roce 2007 objednalo samotné dálkové vyučování 1200 účastníků studujících německý jazyk, zatímco prezenční vyučování téměř 200 000 lidí (Feldmer, 2009). Přesto, že v dnešních moderních LMS bývají implementovány nástroje pro asynchronní či synchronní komunikaci, stále zde chybí moduly podporující také sociální aspekt, tedy ty, které by začlenily do 
této komunikace nonverbální podněty, jako jsou gesta, výrazy obličeje, interakce tváŕí v tvář apod. Některé studie uvádějí, že zásadním faktorem, který ovlivňuje míru využití e-learningu, je zejména pocit nedostatku sociální interakce, která se zdá být klíčovým faktorem v online vzdělávání a který studenti postrádají (Holubcová a kol., 2010). Tento postoj učících se koresponduje s důrazem na sociální rozměr vzdělávání, jenž je dlouhodobě uplatňován v rámci konstruktivistických př́stupů, zdůrazňujících, že lidé své znalosti aktivně konstruují a vytvářejí při interakci sokolím. Učící se je podněcován $\mathrm{k}$ interaktivitě, sociální komunikaci, $\mathrm{k}$ tvorbě vlastních poznatků, ke kritickému posuzování informací, čímž dochází k přechodu od transmisivního vyučování (,tebeurčeni“) $\mathrm{k}$ sebeiniciaci, sebeorganizaci a sebeevaluaci (Kohoutek, 2006). Zejména sociální konstruktivismus, který vychází z prací o sociální dimenzi učení L. S. Vygotského aj., zdůrazňuje nezastupitelnou roli sociální interakce a kultury v procesu konstrukce poznání. V této souvislosti hovoří Říha (2006) také o počitačově podporovaném kolaborativním vzděláváni (computer supported collaborative learning, $C S C L)$, které se odlišuje od dalších forem učení zaměřením na řešení problematiky vztahu kolaborativních procesů učení ICT. Tento přístup legitimizuje využití počítačů jako nástroje pro tvorbu znalostí mezi prostorově vzdálenými účastníky.

\section{Multiuživatelská virtuální prostředí}

Tak, jak se zdokonalují ICT a komunikace jejich prostřednictvím v reálném čase je stále snazší, vzrůstá tedy i zájem uživatelů o co největší přiblížení virtuální komunikace reálnému světu. Proto v současné době zažívají vzrůst sociální sítě umožňující okamžité sdílení informací (Facebook, Twitter ad.), komunikátory umožňující videopřenos (Skype, ICQ ad.), portály nabízející informace v multimediální podobě (stránky televizí, např. iVysílání České televize, BBC ad.) či portály nabízející sdílení informací v podobě videa (YouTube, Google videos ad.) či virtuálních prostředí (Second Life). $Z$ výše uvedených trendů vývoje ICT logicky vyvstává i představa o tom, jakým směrem se budou dále ubírat vývojové aplikace zajištující elearningový způsob výuky. Současné elearningové aplikace zdá se již došly na hranice svých možností v intencích využití stávajících způsobů informačního sdělení v podobě textového a multimediálního vyjádření. B. Brdička (1995) již v 90. letech naznačoval, že přirozeným uživatelským rozhraním konstruktivních výukových aplikací se nepochybně stane virtuální realita, která umožní modelování a experimentování ve virtuálním prostředí. K myšlence využití virtuálního světa uvádí: „Možnost prostorového zobrazení zjištěných závislostí spolu s interaktivní změnou parametrů dovolí mnohem snadnějusí pochopení principů a může přispět třeba i $k$ objevu zcela nových netušených souvislostí“. Za pravdu mu o několik let později dala nejen řada virtuálních 3D prostředí, nejprve v podobě vizuálně propracovaných počítačových her či simulací reálných dějů (napřr. simulátory pro rízení dopravních prostř̌edků apod.), ale zejména multiuživatelská virtuální prostředí (MUVE), která začala být využívána $k$ edukačním účelům. MUVE je definováno jako virtuální 2D či 3D prostředí představující simulaci reálného prostoru (Brdička, 1999). Představuje integraci dosavadně užívaných forem online komunikace a stává se médiem, prostřednictvím něhož je možné vytvářet sociální interakce velmi blízké komunikaci v reálném prostoru. Multiuživatelské virtuální 3D světy se rozvinuly díky konvergenci virtuálních simulací, online počítačových her a sociálních sítí (Gartner, 2007). První sít'ová 3D hra pro více hráčů Maze War ${ }^{1}$ zároveň jako první prrinesla koncept online hráčů reprezentovaných v podobě avatarů (Marešová, 2009).

Vzdělávání v 3D virtuálním prostředí představuje typ výuky, při které jsou učitel a student odděleni časem nebo prostorem (nebo obojím) a učitel poskytuje obsah kurzů (zahrnující zejména distanční studijní opory či řídící a komunikační aplikace) prostrednictvím virtuálního světa. Přenesení tohoto způsobu výuky do $3 \mathrm{D}$ virtuálních světů představuje stále ještě novinku ve vzdělávání, která ale v sobě skýtá řadu dosud ne zcela využitých př́ležitostí. V minulosti bylo těžké zařadit do výuky autentické učební aktivity - at' už $\mathrm{z}$ důvodů finanční náročnosti, nebezpečnosti prostředí či nemožnosti realizovat danou situaci ve školní tř́idě. Tyto hranice ve virtuálních světech mizí. Zde se mohou učící se stát astronomy, chemiky či

1 http://www.digibarn.com/history/04-VCF7MazeWar/index.html 
lékaři bez jakéhokoliv dopadu na reálný svět. $\mathrm{K}$ významným argumentům patř́ také skutečnost, že v informačním věku studenti tráví svi̊j volný čas ve virtuálním prostředí, v důsledku čehož se mohou pro ně tradiční učební metody stát málo motivujícími. Použití virtuálních světů tak může dát učitelům prríležitost získat větší míru zapojení studentů, nebot' zde není studen postaven pouze do role pasivního př́jemce předávaných informací - virtuální svět nabízí řadu možností kreativní kolaborativní práce, která by v reálném světě byla omezena např. hranicemi tř́́dy či počtem účastníků, kteří mohou $\mathrm{v}$ daný moment spolupracovat. Virtuální světy mohou být adaptovány tak, aby implementovaly autentické učební strategie, které jsou zaměřeny na reálný svět, problémy a jejich řešení, používání hraní rolí, problémově zaměřené aktivity, prrípadové studie a účast ve virtuálních komunitách (Kluge, Riley, 2008). Učící se je v takových situacích plně zapojen, nebot' nemůže být pasivní při hraní rolí či účasti na simulaci.

Virtuální světy poskytují vzdělávacím institucím změnu od výuky zprostředkované učitelem na model orientovaný na studenta. Tento model odpovídá konstruktivistickým teoriím, kde učící se využívá své zkušenosti, aby aktivně konstruoval pochopení problému, které dává smysl jemu spíše, než aby mu byl problém předložen $v$ již organizované formě (Kluge, Riley, 2008). Ve virtuálních světech jsou studenti více aktivně zapojeni a zůstávají v procesu konstruování významů na základě jejich zkušeností. Virtuální světy poskytují př́iležitost pro učitele $\mathrm{k}$ implementaci na učicího se orientovaných pedagogických principů, které podporují aktivní, konstruktivistické a na řešení problému zaměřené učení.

\section{Sociální dimenze učení}

MUVE přinesly do procesu edukace novou dimenzi zážitkového vzdělávání. Dalgarno a Lee (2009) ve svých výzkumech 3D vzdělávacího prostředí poukazují na pozitivní efekty vzdělávání v MUVE, a to zejména na pocit identity, „společného byti'“ osob z různých geografických oblastí, přičemž přítomnost dalších osob v učebním prostředí, s nimiž učící se přichází do kontaktu během vzdělávání, zvyšuje vnitřní motivaci a angažovanost jedince, podobně jako je tomu v reálném vzdělávacím prostředí.

Nejvýraznějším aspektem MUVE, kterým se odlišuje od svých předchůdců, tedy zejména počítačových her či simulací reálných prostředí, je prvek, který převzalo z principu sociálních sítí, a tím je aspekt „multiuživatele“. Teprve možnost sdílení stejného virtuálního prostoru umožnilo elektronickým médiím jistým způsobem simulovat interpersonální vztahy. Yee a kol. (2007) studovali sociální normy a chování avatarů, pomocí nichž se uživatelé pohybují ve virtuální realitě, a došli k závěru, že existují významné korelace $\mathrm{v}$ oblasti interpersonálních vztahů mezi reálným a virtuálním světem - např. interpersonální vzdálenost dvou mužů byla delší než u dvou žen, oční kontakt dvou mužů byl kratší než oční kontakt dvou žen, snížení interpersonální vzdálenosti bylo kompenzováno uhýbavým pohledem apod. MUVE tedy vneslo do virtuálního světa některé dosud chybějící aspekty nonverbální komunikace, jako je proxemika, kterou dosavadní nástroje umožňující bezprostřední interpersonální komunikaci (např̀. webkamery) neumožňovaly. Anderson (2009) hovoří o tzv. nonverbální bezprostřednosti, která vzniká při použití emočních výrazů $\mathrm{v}$ online komunikaci (pohyb, oční kontakt, úsměv, gesta, doteky apod.) a která napomáhá psychologickému sblížení. Zároveň toto sbližování probíhá $\mathrm{v}$ relativně bezpečném prostředí, tudíž vytváŕení vazeb mezi jednotlivými členy komunity může být snazší. To si uvědomují také některé firmy, jež využívají virtuální prostředí pro budování mezinárodních virtuálních týmu pracujících na společných aktivitách. Výrazným aspektem této nonverbální bezprostřednosti je také tzv. sociální přítomnost, tedy pocit „být společně u toho“.

Možnost spolupráce a vytváření kolaborativních projektů $\mathrm{v}$ reálném čase tento aspekt ještě umocňují - MUVE umožňuje spolupracovat na společných projektech či při konstrukci vědomostí uživatelům fyzicky vzdáleným, jejichž spolupráce by $\mathrm{v}$ reálném světě byla obtižná a rovněž finančně nákladná. Umožňuje také studentům simulovat reálné situace, při nichž se mohou napřr. naučit pracovat s objekty a demonstrovat ve virtuálním prostoru právě probíranou látku, mohou se účastnit činností a procesů, které by pro ně byly $\mathrm{v}$ reálném prostoru nedostupné (např. tvorba molekulárních struktur, řízení letadla apod.). Naproti tomu tradiční modely e-learningových prostředí (LMS, webové stránky či blogy), založené na samostudiu textových či multimediálních materiálů, při kterých je však 
jedinec v učebním prostředí vizuálně izolován, tento efekt nevytvářejí. MUVE lze tedy považovat za konstruktivní prostředí pro vzdělávání, nebot' není jen zdrojem informací, ale je zároveň závislé na styku s ostatními lidmi, což odpovídá současným didaktickým teoriím zdůrazňujícím sociální aspekt vzdělávání.

$\mathrm{Na}$ význam prŕtomnosti pocitu identity a pocitu komunity při procesu aktivního učení v online učebním prostředí upozorňuje i Wang a kol. (2006). V jejich modelu aktivního učení, který označují jako „cybergogy“

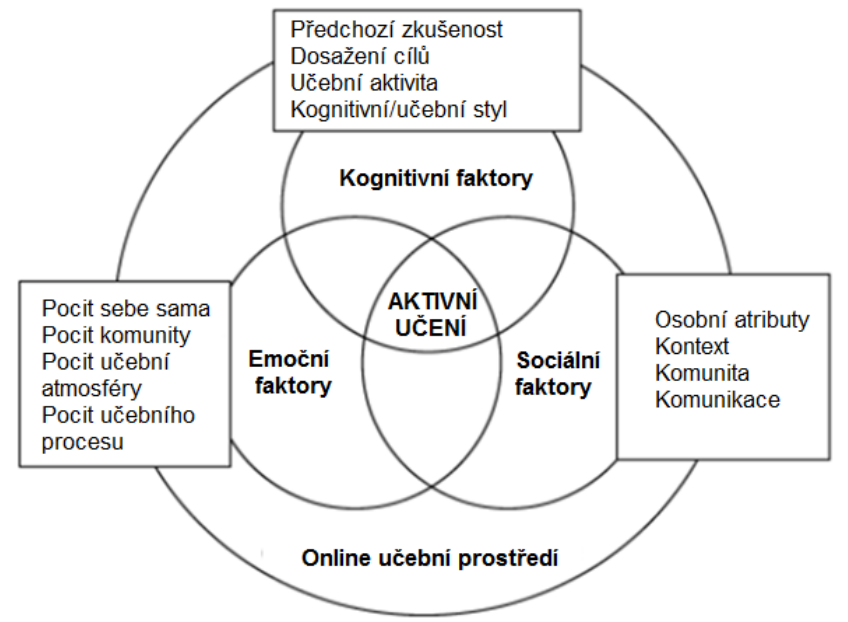

Obr. 8. Adaptovaný model kyberpedagogiky podle: Wang a kol. (2006)
Aspekt spoluvytváření umožňuje přímou spolupráci studentů např. př̀i stavbě virtuálních objektů apod. Práce v malých skupinách, a skupinových fórech, jež vyžadují intenzivní komunikaci, podporuje pocit spoluprítomnosti a vytváření komunitních vztahů, založených na sdílení názorů a idejí, a to bez ohledu na geografické, kulturní či sociální bariéry. V těchto skupinách pak dochází k vytváření sociálních sítí, které podporují sdílení znalostí a neformální výměnu informací.

\section{Závěr}

Inovace v podobě přenesení dosavadních základních prvků e-learningového typu vzdělávání (elektronická distanční studijní opora ${ }^{2}$,

2 Nové možnosti tvorby a hodnocení elektronických distančních studijních opor jsou v současné době na Pedagogické fakultě UP analyzovány v rámci projektu GAČR (GAP407/11/1306 - Evaluace vzdělávacích materiálů určených pro distanční vzdělávání a elearning (2011-2012, hl. řešitel: Milan Klement.) kyberpedagogika ${ }^{2}$ - poukazují na tři oblasti, které musejí být přítomny v př́ípadě, že má být učební strategie úspěšná. Jsou to aspekty kognitivní, sociální a emoční - student musí při online vzdělávání zapojit své předchozí vědomosti, které uvádí do vztahu př́i konstruování nových poznatků, musí být motivován k učení a pozitivně zapojen do učebního procesu. komunikační nástroje, multimediální sdělení) do virtuálního prostředí nabízí učiteli možnost obohatit výuku o sociální aspekt, který může učícímu se napomoci zbavit se pocitu izolovanosti, jenž prožívá v průběhu sebevzdělávání v tradičních e-learningových aplikacích. Každý student je v MUVE vtažen do dění a řešení úkolů na základě dosavadních zkušeností a zároveň je nucen vstupovat do interakce s ostatními účastníky vzdělávání (proto by úkoly měly být tvořeny tak, že je student nemůže vyřešit sám). Je tedy nucen ke konání a jednání, čímž je vtažen do prožitku konstruování vědomostí v maximální možné míře. Jako každý jiný učební nástroj, i MUVE má své limity a omezení, proto je potřebné tato prostředí dále zkoumat a hledat možnosti jejich optimálního využití ve vzdělávání.

Př́spěvek vznikl za podpory projektu GAČR: GAP407/11/1306 - Evaluace vzdělávacích materiálů určených pro distanční vzdělávání a e-learning (2011-2012), hl. řešitel: M. Klement. 


\section{Literatura}

[1] AIMARD, V., MC CULlOUGH, C. How do trainers, teachers and learners rate e-learning? Cedefop [online]. 2006, 52 s. [cit. 2012-03-14]. Dostupné

$<$ http://www.cedefop.europa.eu/etv/Upload/Exch ange_views/Surveys/Report_survey_Teachers_an d Learners and e-learning final.pdf $>$.

[2] ANDERSON, T. L. Online Instructor Immediacy and Instructor-Student Relationships in Second Life. In: Wankel, Ch., Kingsley, J. Higher Education in Virtual Worlds. Teaching and Learning in Second Life. Bingley, UK : Emerald Group Publishing Limited, 2009. ISBN 978-1-84950-609-0.

[3] BRDIČKA, B. Učení s počítačem. Virtuální realita. Bobrův pomocník [online]. 1995 [cit. 2011-02-05]. Dostupné $<$ http://it.pedf.cuni.cz/ bobr/ucspoc/virtreal.htm>

[4] BRDIČKA, B. Víceuživatelské virtuální prostředí a možnosti jeho využití ve vzdělávání. Bobrưv pomocník [online]. 1999 [cit. 2012-0305]. Dostupné $<$ http://it.pedf.cuni.cz/ bobr/MUVE/> .

[5] DALGARNO, B., LEE, M. J. W. What are the learning affordances of 3-D virtual environments? British Journal of Educational Technology [online]. Vol. 41, Issue 1, pp. 10-32, 2009. DOI: $10.1111 / \mathrm{j} .1467-8535.2009 .01038 . x$ [cit. 2012-03-05]. Dostupné z: <http://onlinelibrary.wiley.com/doi/10.1111/j.146 7-8535.2009.01038.x/full>.

[6] FELDMER, S. Výuka jazyků online je žádaná. Od e-learningu po blended learning. $D A F$ [online]. 2009. [cit. 2012-04-05]. Dostupné z: http://www.goethe.de/ges/spa/dos/daf/spr/cs4590 436.htm

[7] GARTNER RESEARCH. Gartner says 80 percent of aktive Internet users will have a "Second Life" in the virtual world by the end of 2011 [online]. 24. 4. 2007 [cit. 2012-04-25]. Dostupné <http://www.gartner.com/it/page.jsp?id=503861> [8] HOLUBCOVÁ, E, ILKOVÁ, M., JÍLKOVÁ D., JUHAŇÁK, L., KANTOROVÁ, K., RYCHTOVÁ, V. Aplikace vzdělávacích a kolaborativních nástrojů ve virtuálním světě Second Life - projekt VIAKISK. Inflow: information journal [online]. 2010, roč. 3 , č. 1 [cit. 2012-04-15]. Dostupné z: $<$ http://www.inflow.cz/aplikace-vzdelavacich- kolaborativnich-nastroju-ve-virtualnim-svetesecond-life-projekt-viakisk>. ISSN 1802-9736. [9] KLEMENT, M. Možnosti hodnocení elektronických studijních opor. In T. Janík, P. Knecht, \& S. Šebestová (Eds.), Smíšený design v pedagogickém výzkumu: Sbornik přispěvkỉ z 19. výročni konference České asociace pedagogického výzkumu [online]. Brno: Masarykova univerzita, 2011, s. 91-97, doi: 10.5817/PdF.P210-CAPV-2012-25. [cit. 201203-06]. Dostupné z: <http://www.ped.muni.cz/capv2011/sbornikprisp evku/klement.pdf $>$.

[10] KLUGE, S., RILEY, L. Teaching in Virtual Worlds: Opportunities and Challenges. Issues in Informing Science and Information Technology [online]. Vol. 5, 2008, pp. 127-135 [cit. 2012-0303]. Dostupné

$<$ http://proceedings.informingscience.org/InSITE 2008/IISITv5p127-135Kluge459.pdf >.

[11] KOHOUTEK, R. Pedagogický konstruktivismus. ABZ slovník cizích slov [online]. 2006 [cit. 2012-04-06]. Dostupné z: $<$ http://slovnik-cizich-

slov.abz.cz/web.php/slovo/pedagogickykonstruktivismus>.

[12] MAREŠOVÁ, H. E-learning v multiuživatelském virtuálním prostředí. Journal of Technology and Information Education. 1/2009, Volume 1, Issue 1, s. 39-44. ISSN 1803$537 \mathrm{X}$

[13] NOCAR, D. E-learning $v$ distančním vzdělávání [online]. 2004 [cit. 2012-04-06]. Dostupné $\mathrm{Z}$ : $<$ http://www.cdiv.upol.cz/www/Konference/NCD iV 2004/Nocar.pdf>

[14] PRŮCHA, J. a kol. Pedagogická encyklopedie. Praha: Portál, 2009, 935 s. ISBN 978-80-7367-546-2

[15] ŘÍHA， Daniel. Implementace prostředi neimerzivní virtuální reality v rámci "Kunst am Bau” [online]. 2006 [cit. 2012-04-05]. Dostupné $\mathrm{Z}$

$<$ http://everest.natur.cuni.cz/konference/2006/pris pevek/riha.pdf $>$.

[16] WANG, M., KANG, M. Cybergogy for Engaged Learning: A Framework for Creating Learner Engagement through Information and Communication Technology. Engaged Learning with Emerging Technologies [online]. 2006, 225253, DOI: 10.1007/1-4020-3669-8_11 [cit. 201204-02].

Dostupné

$\mathrm{z}:$ 
$<$ http://www.springerlink.com/content/p2 1 m7705 2377782w/fulltext.pdf>

[17] YEE, N., BAILENSON, J.N., URBANEK, M., CHANG, F., MERGET, D. The Unbearable Likeness of Being Digital: The Persistence of Nonverbal Social Norms in Online Virtual Environments. The Journal of CyberPsychology and Behavior [online]. No. 10, pp. 115-121, 2007 [cit. 2012-04-02].

$<$ http://www.nickyee.com/pubs/Yee,\%20Bailenso $\mathrm{n}, \%$ 20Urbanek, \%20Chang\%20\&\%20Merget $\% 20$ -\%20SL\%20NonVerbal.pdf>.

Lektoroval: Mgr. Martin Havelka, Ph.D.
Hana Marešová, PhDr., Ph.D.,

Katedra českého jazyka a literatury,

Pedagogická fakulta UP, Žižkovo nám. 5, 771 40 Olomouc, Č R, tel. 00420585635 607, fax 00420585231 400, e-mail: hana.maresova@upol.cz Milan Klement, PhDr., Ph.D., Katedra technické a informační výchovy, Pedagogická fakulta UP, Žižkovo nám. 5, 771 40 Olomouc, Č R, tel. 00420585635811 , fax 00420585231400 , e-mail: milan.klement@upol.cz 